\title{
Home Garden, Desirable Dietary Pattern And Food Expenditure In Banjarnegara Regency
}

\author{
By \\ Uni Wuriyaningrum ${ }^{*}$, Istiqomah, Suprapto \\ Faculty of Economics and Business, Universitas Jenderal Soedirman \\ ${ }^{*}$ Corresponding Author: niwuriyaningrum@gmail.com
}

Submission: November 20, 2019; Accepted: February 19, 2020

\begin{abstract}
The study is based on the patterns of food consumption in the community that has not reached the minimum nutritional standard for activities. This study aimed to determine the impact of the Sustainable Food Neighborhood (Kawasan Rumah Pangan Lestari/KRPL) program on the desirable dietary pattern (DDP) score, energy consumption, protein consumption and household food expenditure in Banjarnegara Regency. Primary data were obtained from the KRPL beneficiaries and non-KRPL. secondary data were obtained from Food Security Agency of the Ministry of Agriculture, the Central Java Province Food Security Department and the Banjarnegara Regency Food Security Department. The analytical tool used is z-test. The result indicated that there were significant differences in DDP, energy consumption, protein consumption and food expenditure between the KRPL and non-KRPL groups. DDP score of KRPL group was higher than non-KRPL group. This indicated that consumption of the KRPL group was more diverse and nutritionally balanced. The energy consumption of the KRPL group was higher than the non-KRPL group, so that the energy adequacy of the KRPL group was closer to the DDP. Protein consumption in the KRPL group was higher and has met the DDP, while the non-KRPL group has not met the DDP. The food expenditure in the KRPL group was lower than the non-KRPL group because there were savings on the food spending. The results imply that in order to increase the DDP, energy consumption, protein consumption and to save household food expenditure, the use of the yard should be optimize to increase household food supply and diversity.
\end{abstract}

Keywords: Sustainable Food Neighborhood (KRPL), energy consumption, protein consumption, food expenditure, desirable dietary patternscore.

\footnotetext{
ABSTRAK

Penelitian ini berlatar belakang pola konsumsi pangan masyarakat yang belum mencapai standar pemenuhan kebutuhan minimal untuk beraktifitas. Penelitian ini bertujuan untuk mengetahui dampak Program Kawasan RumahPangan Lestari (KRPL) terhadap skor PPH, konsumsi energi, konsumsi protein dan pengeluaran bahan pangan rumah tangga di Kabupaten Banjarnegara. Data primer bersumber dari kelompok penerima manfaat KRPL dan non KRPL. Data sekunder diperoleh dari Badan Ketahanan Pangan Kementerian Pertanian, Dinas Ketahanan Pangan Provinsi Jawa Tengah dan Dinas Ketahanan Pangan Kabupaten Banjarnegara. Alat analisis yang digunakan yaitu uji beda antara kelompok penerima manfaat KRPL dan kelompok non penerima manfaat KRPL. Hasil analisis menunjukkan bahwa terdapat perbedaan skor PPH, konsumsi energi, konsumsi protein dan pengeluaran bahan pangan yang signifikan antara kelompok KRPL dan non KRPL. Skor PPH kelompok KRPL tebih tinggi dari non KRPL. Hal tersebut menunjukkan konsumsi kelompok KRPL lebih beragam dan bergizi seimbang. Konsumsi energi kelompok KRPL lebih tinggi dari kelompok non KRPL, sehingga kecukupan energi kelompok KRPL lebih mendekati angka
} 
kecukupan energi. Konsumsi protein kelompok KRPL lebih tinggi dan sudah mencukupi angka kecukupan gizi, sedangkan kelompok non KRPL belum mencukupi angka kecukupan gizi. Pengeluaran bahan pangan kelompok KRPL lebih rendah dari kelompok non KRP karena terdapat penghematan belanja bahan pangan. Dengan demikian, Program KRPL berdampak pada peningkatan skor PPH, konsumsi energi dan penghematan pengeluaran bahan pangan rumah tangga. Hasil tersebut mengimplikasikan bahwa dalam upaya meningkatkan skor PPH, konsumsi energi dan konsumsi protein serta menghemat pengeluaran bahan pangan rumah tangga, pemanfaatan pekarangan sebaiknya dioptimalkan untuk meningkatkan ketersediaan dan keragaman pangan.

Kata Kunci: Kawasan Rumah Pangan Lestari (KRPL), Konsumsi Energi, Konsumsi Protein, Pengeluaran Pangan, Skor PPH

\section{INTRODUCTION}

Food is a basic human need and its fulfillment is a human right guaranteed in the 1945 Constitution of the Republic of Indonesia as a basic component to realize quality human resources. Development of food security is carried out through improving the quality of public food consumption and nutrition, meaning that food consumption is not only considered in terms of availability, but also quality. The Recommended Dietary Allowance (RDA) is used as a qualitative reference for food consumption. The average per capita per day for energy is 2,150 kilocaries and 57 grams of protein, while RDA is used as a reference to evaluate the level of dietary pattern with a score of 100 as an ideal pattern. Based on the Minister of Agriculture Regulation No. 65 of 2010, the population with food consumption of less than $1,400 \mathrm{kcal}(70 \% \mathrm{RDA})$ is included in the food insecurity category. Figures of Indonesia food insecurity in 2012-2016 can be seen in the following table.

Table 1. Figure of National Food Insecurity in 2012-2016

\begin{tabular}{|c|c|c|c|c|c|c|}
\hline Year & $\begin{array}{l}\text { Number of People } \\
\text { with Very Low } \\
\text { Food Security } \\
\text { (<70\%RDA) }\end{array}$ & $\%$ & $\begin{array}{l}\text { Number of People } \\
\text { with Low Food } \\
\text { Security (70\%- } \\
\text { 89.9\% RDA) }\end{array}$ & $\%$ & $\begin{array}{c}\text { Number of } \\
\text { People with Food } \\
\text { Security } \\
\text { (>=90\% RDA) }\end{array}$ & $\%$ \\
\hline 2012 & $47,842,490$ & 19.52 & $80,832,494$ & 32.97 & $116,463,438$ & 47.51 \\
\hline 2013 & $46,399,355$ & 18.68 & $84,091,618$ & 33.84 & $117,956,185$ & 47.48 \\
\hline 2014 & $43,739,341$ & 16.94 & $84,823,188$ & 33.16 & $122,825,321$ & 49.90 \\
\hline 2015 & $33,030,182$ & 12.96 & $72,813,600$ & 28.57 & $149,052,869$ & 58.48 \\
\hline 2016 & $32,734,074$ & 12.69 & $70,039,317$ & 27.16 & $155,116,930$ & 60.15 \\
\hline
\end{tabular}

Source: Food Security Agency (BKP) Ministry of Agriculture, 2017

Based on Table 1, number of people with low and very low food security is 70,039 million and 32,734 million people in 2016, respectively. Although this number tends to decrease from year to year, the government's special intervention is needed in order to realize food independence.

Food utilization is one element of food security. In this case, food utilization describes how available and accessible foods to the community are used or consumed to create healthy and productive human resources. The more diverse food groups consumed by the community, the better the food quality. According to Grebmer in Hermanto (2015), one of the composite indexes that can be used to measure the indirect impact of food utilization is the Global Hunger Index (GHI). GHI is a composite index of data on the proportion of undernourished population, the proportion of children under five years old, underweight children, and mortality rate of children under five years old. East and Southeast Asia are among the progressive regions in handling food insecurity problems, namely from GHI of 16.4 in 1990 to 7.6 in 2014. Thailand with a GHI score of 5.0 ranks 1 of 76 countries, while Indonesia with a GHI value of 10.3 ranks 22 below Thailand, Malaysia and Vietnam. The more diverse food groups consumed by the community, the better the food quality. 
Development of national food security towards food independence starts from food security at the household level, including through the aspect of food consumption. One form of food security at household level is diversification of food consumption based on local resources that may affect consumption pattern at household level. Consumption pattern is a food composition including the type and average amount of foodstuffs per person per day, commonly consumed/eaten by the population within a certain period (the Regulation of Minister of Agriculture No. 65/2010). Most of Indonesia's population consume vegetables $(94.8 \%)$, but only a few consume fruits $(33.2 \%)$. The average vegetable consumption is 70.0 grams/person/day and the average fruit consumption is 38.8 grams/person/day. The total consumption of vegetables and fruits is $108.8 \mathrm{grams} /$ person/day. When compared to the RDA of vegetables of 171.0 grams/cap/day and fruits of 97.8 grams/cap/day, the Indonesian consumption of vegetables and fruits is relatively low. $97.1 \%$ of the population consume less vegetables and fruits. Based on the age group, adolescent is the age group with the lowest consumption of vegetables and fruits (98.4\%). In conclusion, the consumption of vegetables and fruits in Indonesia is relatively low in the context of balanced nutrition according to age group, both in urban and rural areas and the lowest is in the adolescent age group (Hermina \&Prihatini S, 2014).

According to Becker in Fatmah (2014:68), healthy behavior is a behavior related to one's efforts or activities to maintain and improve health. This behavior includes consuming foods that meet the elements of balanced nutrition with appropriate diet. The balanced nutrition is in terms of quality (containing the substances needed by the body) and quantity in the sense that the amount is sufficient to meet the body's needs (no more, no less). The DDP is a composition of a variety of foods based on the proportion of energy balance from various food groups to meet energy and other nutrients, both in quantity and quality by considering the aspect of acceptability, availability of food, economy, culture and religion. Nationally, DDP scores in 2013-2017 can be seen at Table 2.

Table 2. Development of National DDP Score 2013-2017

\begin{tabular}{llrrrrrr}
\hline No. & Food Group & Standard & 2013 & 2014 & 2015 & 2016 & 2017 \\
\hline 1 & Grains & 25.0 & 25.00 & 25.00 & 25.00 & 25.00 & 25.00 \\
2 & Bulbs & 2.5 & 2.50 & 2.50 & 2.50 & 2.50 & 2.50 \\
3 & Animal Foods & 24.0 & 14.30 & 13.30 & 13.84 & 14.85 & 15.49 \\
4 & Oils \& Fats & 5.0 & 5.00 & 5.00 & 5.00 & 5.00 & 5.00 \\
5 & Oily Fruits/Seeds & 1.0 & 1.00 & 1.00 & 1.00 & 1.00 & 1.00 \\
6 & Nuts & 10.0 & 10.00 & 10.00 & 10.00 & 10.00 & 9.81 \\
7 & Sugar & 2.5 & 2.50 & 2.50 & 2.50 & 2.50 & 2.50 \\
8 & Vegetables \& Fruits & 30.0 & 24.20 & 23.50 & 21.75 & 20.67 & 21.74 \\
9 & Others & 0.0 & 0.00 & 0.00 & 0.00 & 0.00 & 0.00 \\
\hline & DDP Score & 100.0 & 84.50 & 82.80 & 81.59 & 81.52 & 83,04 \\
\hline
\end{tabular}

Source: Performance Report of Food Security Agency (BKP) Ministry of Agriculture, 2017

Based on Table 2, National DDP score is below the fulfillment standard or total score of 100 . The national DDP score shows fluctuations from 2013 to 2017. The highest DDP score is achieved in 2013.

The national DDP score is derived from the calculation of the DDP score of all provinces in Indonesia. The desirable DDP for Central Java Province from 2013 to 2017 can be seen at Table 3.

Table 3. Desirable Dietary Pattern (Recommended Dietary Intake) Score of Central Java in 2013-2014

\begin{tabular}{llllllll}
\hline No & Food Group & Standard & 2013 & 2014 & 2015 & 2016 & 2017 \\
\hline 1 & Grains & 25.0 & 25.00 & 25.00 & 25.0 & 24.85 & 25.0 \\
2 & Bulbs & 2.5 & 2.19 & 2.21 & 2.1 & 1.90 & 0.88 \\
3 & Animal Foods & 24.0 & 17.62 & 17.96 & 17.7 & 19.22 & 19.45 \\
4 & Oils \& Fats & 5.0 & 3.91 & 5.00 & 5.0 & 5.00 & 5.00 \\
5 & Oily Fruits/Seeds & 1.0 & 0.79 & 1.00 & 1.0 & 0.93 & 1.00 \\
6 & Nuts & 10.0 & 10.00 & 10.00 & 10.0 & 10.00 & 6.87 \\
7 & Sugar & 2.5 & 1.78 & 1.79 & 1.8 & 1.97 & 2.50
\end{tabular}


Home Garden, Desirable .... (Wuriyaningrum, et al.)

\begin{tabular}{|c|c|c|c|c|c|c|c|}
\hline No & Food Group & Standard & 2013 & 2014 & 2015 & 2016 & 2017 \\
\hline 8 & Vegetables \& Fruits & 30.0 & 29.06 & 28.82 & 28.9 & 27.96 & 25.71 \\
\hline \multirow[t]{2}{*}{9} & Others & 0.0 & 0.0 & 0.0 & 0.0 & 0.0 & 0.0 \\
\hline & DDP Score & 100.0 & 90.35 & 91.78 & 91.5 & 91.84 & 86.41 \\
\hline
\end{tabular}

Source: Food Security Agency (BKP) of Central Java Province

Based on Table 3, DDP score of Central Java is below the energy adequacy standard, even there is a decrease in 2017. Food groups to be improved are mainly animal foods, and vegetables and fruits. Animal foods consumption shows an upward trend, although not significant. While consumption of vegetables and fruits shows a downward trend.

The DDP scores of Banjarnegara Regency in 2012-2017 can be seen in Table 4.

Table 4. DDP Score of Banjarnegara Regency in 2014-2018

\begin{tabular}{llrrrrrr}
\hline No & Food Group & Standard & 2014 & 2015 & 2016 & 2017 & 2018 \\
\hline 1 & Grains & 25.0 & 21.2 & 25 & 25 & 24 & 21.7 \\
2 & Bulbs & 2.5 & 1.4 & 1.5 & 1.2 & 1 & 0.9 \\
3 & Animal Foods & 24.0 & 19.5 & 20.0 & 19.9 & 19.6 & 23.4 \\
4 & Oils \& Fats & 5.0 & 3.6 & 2.4 & 5 & 4.7 & 4.7 \\
5 & Oily Fruits/Seeds & 1.0 & 0.8 & 0.7 & 0.6 & 0.8 & 0.8 \\
6 & Nuts & 10.0 & 10.0 & 10.0 & 10.0 & 10.0 & 10.0 \\
7 & Sugar & 2.5 & 0.8 & 0.8 & 0.8 & 1.2 & 1.2 \\
8 & Vegetables \& Fruits & 30.0 & 30.0 & 29.3 & 27.4 & 24.3 & 23.1 \\
9 & Others & 0.0 & 0.0 & 0.0 & 0.0 & 0.0 & 0.0 \\
\hline & DDP Score & 100.0 & 87.3 & 90 & 90 & 85.7 & 85.9 \\
\hline
\end{tabular}

Source: Food Security Agency Banjarnegara Regency, 2018

The DDP score of Banjarnegara Regency in 2017 is 85.7 lower than the DPP score of Banyumas Regency of 90.01. In the same year, the DDP score of Banjarnegara Regency is relatively higher than that of Purbalingga Regency of 85.23. Based on this data, the achievement of DDP score of Banjarnegara Regency has not been ideal. The Recommended Dietary Allowances of Banjarnegara Regency in 2014-2018 can be seen in the following table.

Table 5. Energy and Protein Consumption of Banjarnegara Regency in 2014-2018

\begin{tabular}{lccc}
\hline No. & Year & $\begin{array}{c}\text { Energy Consumption } \\
\text { (kcal/cap/day) }\end{array}$ & $\begin{array}{c}\text { Protein Consumption } \\
\text { (gram/cap/day) }\end{array}$ \\
\hline 1 & 2014 & $1,619.3$ & 47.0 \\
2 & 2015 & $2,110.2$ & 57.0 \\
3 & 2016 & $2,013.6$ & 51.4 \\
4 & 2017 & $1,513.4$ & 59.2 \\
5 & 2018 & $1,792.4$ & 56.8 \\
\hline
\end{tabular}

Source: Food Security Department Banjarnegara Regency, 2018

Based on table above, energy consumption in 2014-2018 tends to fluctuate. The highest energy consumption is in 2015 of $2,110.2 \mathrm{kcal} / \mathrm{cap} /$ day, while the lowest energy consumption is in 2017 of $1,513.4 \mathrm{kcal} / \mathrm{cap} / \mathrm{day}$. The protein consumption of Banjarnegara Regency in 2014-2018 also fluctuates, but it has met the recommended dietary allowance in 2015. This is indicated by the protein consumption of more than 50 grams/cap/day. The highest protein consumption is in 2017 of 59.2 grams/cap/day and the lowest protein consumption is in 2014 of 47 grams/cap/day.

Based on the description above, the achievement of DDP score of Banjarnegara Regency has not been ideal and the energy consumption has not met energy adequacy ratio, while the protein adequacy has met the recommended dietary allowance. Based on the data of the strategic plan, the target of the achievement of DDP score of Banjarnegara Regency Food Security Agency in 2018 is 90, 
while the realization is 85.9 . The energy consumption of $1,377 \mathrm{kcal} / \mathrm{cap} /$ day is below the recommended dietary allowance of $2,150 \mathrm{kcal} / \mathrm{cap} /$ day.

One of the government's policies in increasing the DDP score is Food Consumption Diversification Acceleration Program through the concept of Sustainable Food Neighborhood (Kawasan Rumah Pangan Lestari/KRPL). This program is expected to improve the quality of public food consumption to create better consumption patterns (Technical Guidance of KRPL, 2018). The program to optimize the yard utilization that can become a family food resource is not only limited to plants as a source of carbohydrates, vitamins and minerals, but also to livestock and fish as a source of protein. Diversity of diet, founded on diverse farming system, delivers better nutrition and greater health, with additional benefits for human productivity and livelihoods (Frison et al., 2011).

Since 2010, the Ministry of Agriculture through the Food Security Agency has implemented Food Consumption Diversification Acceleration Program as an embodiment of Presidential Decree No. 22 of 2009 on Policy on Food Consumption Diversification Acceleration Based on Local Resources, followed up by Regulationof the Minister of Agriculture No. 43 of 2009 on Policy on Food Consumption Diversification Acceleration Program Based on Local Resources. These regulations are a reference to encourage efforts to accelerate food consumption diversification based on local wisdom and integrated cooperation between local governments and the community. The home garden program with neighborhood approach could be used as a means to promote rural development as it satisfies household vegetable (and in some household also animal protein) consumption, provides income, and protects environment (Istiqomah and Fitrijati, 2015).

In 2008, the Food Security Agency through the center for Consumption Diversification and Food Security has re-launched the Concept of Sustainable Food Neighborhood and Banjarnegara Regency has implemented the program. The program beneficiaries are 5 (five) women farmer groups in 5 (five) villages in Banjarnegara Regency, namely Dewi Lestari, Masaran Village Bawang Sub-District, 2) Dadi Rahayu, Gumingsir Village Pagetan Sub-District, 3) Budi Lestari, Sikumpul Village Kalibening SubDistrict, 4) Kartini, Gembongan Village Sigaluh Sub-District, 5) Melati, Darmayasa Village, Pejawaran Sub-District. This program is expected to improve the quality of public food consumption to create good food consumption patterns. The female farmer groups as KRPL beneficiaries have more household food availability than non-KRPL. There have been positive impacts of home gardens such as addressing food insecurity and malnutrition as well as providing additional benefits such as income and livelihood opportunities for resource-poor families (Galhena et al., 2013). The success of Food Consumption Diversification is reflected in its outcome indicators in the form of increased frequency of consumption of vegetables, fruits and protein, as well as benefit indicators, namely increased DDP score (Technical Guidance of KRPL, 2018). The hypotheses of this study were as follows:

1. $\mathrm{H}_{0}$ : There is a difference in DDP scores between the KRPL beneficiary group and the non-KRPL beneficiary group.

$\mathrm{H}_{a}$ : The DDP scores of the KRPL beneficiary group is higher than the non-KRPL group.

2. $\mathrm{H}_{0}$ : There is a difference in energy consumption between the KRPL beneficiary group and the non-KRPL beneficiary group.

$\mathrm{H}_{a}$ : The energy consumption of the KRPL beneficiary group is higher than the non-KRPL group.

3. $\mathrm{H}_{0}:$ There is a difference in protein consumption between the KRPL beneficiary group and the non-KRPL beneficiary group.

$\mathrm{H}_{a}$ : The protein consumption of the KRPL beneficiary group is higher than the non-KRPL group.

4. $\mathrm{H}_{0}$ : There is a difference in food expenditure between the KRPL beneficiary group and the non-KRPL beneficiary group.

$\mathrm{H}_{a}$ : The food expenditureof the KRPL beneficiary group is smaller than the non-KRPL group.

\section{METHOD}

This study used a comparative method. A comparative evaluation research is an evaluation research that compares the potential and policy problem, policy agenda, policy maker, policy formulation, policy implementation, output, and policy impact (Sugiyono, 2017:541). This study was conducted in 
Banjarnegara Sub-District as one of the beneficiaries of the KRPL Program. The objects in this study were of KRPL beneficiary households and non-KRPL beneficiary households in BanjarnegaraRegency in 2018 carried out in five villages namely Gumingsir Village PagentanSub-District, Masaran Village BawangSub-District, Darmayasa Village Pejawaran Sub-District, Sikumpul Village KalibeningSubDistrict and Gembongan VillageSigaluh Sub-District. The number of KRPL respondentswas 105 households, while the number of non-KRPL respondents was 85 households.

Data used in this study were primary and secondary data. Primary data was data obtained directly from households in the study location through interview on food consumption and household expenditure. Data collection on food was carried out using food recall method. Recall was conducted twice and each for consumption for $1 \times 24$ hours. Secondary data was data obtained from the literature and the Ministry of Agriculture, the Food Security Department of Banjarnegara Regency, the Department of Agriculture and Animal Husbandry of Banjarnegara Regency.

The technical analysis is the calculation of DDP score, energy consumption, protein consumption, and household food expenditure between the KRPL beneficiary group and the non-KRPL beneficiary group. The difference between two independent means (large sample) was performed using the $z$ test (Putrawan, 2017:43). This test was used to analyze the difference in DDP score, energy consumption, protein consumption, and household food expenditure between the KRPL group and the non-KRPL group. The formula of hypothesis testing as follows :

$$
Z_{\text {test }}=\frac{\overline{\mathrm{U}}_{1}-\overline{\mathrm{U}}_{2}}{\sqrt{\frac{S_{1}^{2}}{n_{1}}+\frac{S_{2}^{2}}{n_{2}}}}
$$

$\bar{U}_{1}$ : mean of DDP score/energy consumption/protein consumption/food expenditure of KRPL group

$\overline{\mathrm{U}}_{2}:$ mean of DDP score/ energy consumption/protein consumption/food expenditure of non KRPL group

$S_{1}^{2}$ : standard deviation of DDP score/energy consumption/protein consumption/food expenditure of KRPL group

$S_{2}^{2}$ : standard deviation of DDP score/energy consumption/protein consumption/food expenditure of non KRPL group

$n_{1}$ : sample size of KRPL group

$n_{2}$ : sample size of non KRPL group

Testing criteria for DDP score/energy consumption/protein consumption :

- $\quad$ Ho is received if $Z_{\text {test }} \leq+Z_{\alpha}$

- $\quad$ Ha is rejected if $Z_{\text {test }}>+Z_{\alpha}$

Testing criteria for food expenditure :

- Ho is receiver if $-Z_{\text {test }} \leq+Z_{\alpha}$

- Ha is rejected if $Z_{\text {test }}>+-Z_{\alpha}$

\section{RESULTS AND DISCUSSION}

One of the government's programsas an effort to utilize yard is KRPL Program. Based on the Technical Guidance of KRPL (2018), KRPL Program was carried out through efforts to empower women and other community groups to cultivate various types of plants, livestock and fish in addition to meeting the availability of food containing carbohydrates, proteins, vitamins and minerals as well as processing their results. Based on the results of this study, the impacts of KRPL program on DESIRABLE DIETARY PATTERNscore, energy consumption, protein consumption and household foodstuff expenditure in Banjarnegara Regency are as follows: 


\section{Analysis of DDP Score}

Based on the calculation, it was obtained DDP score of the KRPL group as follows:

Table 6. DDP Score of KRPL Group

\begin{tabular}{|c|c|c|c|c|c|c|c|}
\hline No & Food Group & Standard & Gumingsir & Masaran & Darmayasa & Sikumpul & Gembongan \\
\hline 1 & Grains & 25.0 & 25.0 & 24.8 & 25.0 & 25.0 & 24.5 \\
\hline 2 & Bulbs & 2.5 & 0.3 & 0.7 & 1.8 & 0.2 & 0.2 \\
\hline 3 & Animal Foods & 24.0 & 19.7 & 19.2 & 14.6 & 16.8 & 15.4 \\
\hline 4 & Oils \& Fats & 5.0 & 4.7 & 3.3 & 2.8 & 3.4 & 4.0 \\
\hline 5 & Oily Fruits/Seeds & 1.0 & 1.0 & 1.0 & 1.0 & 1.0 & 1.0 \\
\hline 6 & Nuts & 10.0 & 10.0 & 10.0 & 10.0 & 10.0 & 10.0 \\
\hline 7 & Sugar & 2.5 & 1.0 & 1.1 & 1.1 & 1.3 & 1.6 \\
\hline 8 & Vegetables \& Fruits & 30.0 & 24.1 & 25.3 & 28.0 & 25.9 & 24.3 \\
\hline 9 & Others & 0.0 & 0.0 & 0.0 & 0.0 & 0.0 & 0.0 \\
\hline & DDP Score & 100.0 & 85.7 & 85.3 & 84.3 & 83.7 & 81.0 \\
\hline
\end{tabular}

\section{Source:Primary Data Processed}

The DDP score of the KRPL group ranges from 81.0 to 85.7. The highest DDP score is 85.7 in Gumingsir Village Pagentan Sub-District, while the lowest DDP score is 81.0 in Gembongan Village Sigaluh Sub-District.

Based on the calculation, it is obtained DDP score of the non-KRPL group as follows:

Table7 . DDP Score of Non-KRPL Group

\begin{tabular}{clrrrrrr}
\hline No & Food Group & Standard & Gumingsir & Masaran & Darmayasa & Sikumpul & Gembongan \\
\hline 1 & Grains & 25.0 & 25.0 & 24.6 & 25.0 & 23.7 & 24.4 \\
2 & Bulbs & 2.5 & 0.4 & 0.1 & 0.6 & 0.1 & 0.3 \\
3 & Animal Foods & 24.0 & 13.4 & 7.8 & 15.6 & 21.5 & 17.7 \\
4 & Oils \& Fats & 5.0 & 4.0 & 4.2 & 2.7 & 4.2 & 4.8 \\
5 & Oily Fruits/Seeds & 1.0 & 1.0 & 0.8 & 1.0 & 0.7 & 1.0 \\
6 & Nuts & 10.0 & 10.0 & 8.4 & 10.0 & 8.2 & 8.8 \\
7 & Sugar & 2.5 & 1.1 & 1.1 & 1.4 & 0.7 & 0.9 \\
8 & Vegetables \& Fruits & 30.0 & 20.3 & 18.1 & 18.3 & 16.6 & 17.2 \\
9 & Others & 0.0 & 0.0 & 0.0 & 0.0 & 0.0 & 0.0 \\
\hline \multicolumn{7}{c}{ Source: Primary Data Processed }
\end{tabular}

The results of z-test on DDP score based on SPSSS analysis are as follows.

Table 8. Group Statistic of Analysis Result of DDP Score Using SPSS

\begin{tabular}{|c|c|c|c|c|c|c|}
\hline & Group & $\mathrm{N}$ & & & Std. Deviation & Std. Error Mean \\
\hline \multirow[t]{2}{*}{ DDP } & KRPL & & 5 & 83.9800 & 1.85122 & .82789 \\
\hline & Non-KRPL & & 5 & 73.1600 & 4.5197 & 2.02129 \\
\hline
\end{tabular}

Source: Primary Data Processed Using SPSS

Table 9. Result of Independent Samples z Test of DDP Score

\section{z-test for Equality of Means}

\begin{tabular}{|c|c|c|c|c|}
\hline \multicolumn{5}{|c|}{ z-test for Equality of Means } \\
\hline \multirow[t]{2}{*}{$\begin{array}{l}\text { Sig.(2- } \\
\text { tailed) }\end{array}$} & \multirow[t]{2}{*}{$\begin{array}{c}\text { Mean } \\
\text { Difference }\end{array}$} & \multirow[t]{2}{*}{$\begin{array}{l}\text { Std. Error } \\
\text { Diference }\end{array}$} & \multicolumn{2}{|c|}{$\begin{array}{l}\text { 95\% Confidence } \\
\text { Interval of the } \\
\text { Difference }\end{array}$} \\
\hline & & & Lower & Upper \\
\hline .001 & 10.82000 & 2.18426 & 5.78308 & 15.85692 \\
\hline .004 & 10.82000 & 2.18426 & 5.30100 & 16.33900 \\
\hline
\end{tabular}


Based on the table of output of independent samples $z$ test in the Equal Variances Assumed section, it is obtained Sig. (2-tailed) value of $0.001<0.005$, then as the basis for decision making in the independent samples $\mathrm{z}$ test, it can be concluded that $\mathrm{H}_{0}$ is rejected and $\mathrm{Ha}$ is accepted. Thus, it can be concluded that there is a significant difference in DDP scores between the KRPL group and the nonKRPL group. The results indicate that there is a significant difference in DDP scores between the KRPL beneficiary group and the non-KRPL beneficiary group. The DDP score of the KRPL beneficiary group is 83.98, while the DDP score of the non-KRPL beneficiary group is 73.16.

The KRPL group has a higher value in all food groups than the non-KRPL group. This indicates that the KRPL group members have higher food quality as indicated by the higher DDP score. The higher the DDP score, the more diverse food consumption patterns. This finding is in accordance with Jones et al. (2014) that the diversity of agricultural production has the potential to affect the consumption diversity, nutritional adequacy, and nutritional status of the community. The diversity of agricultural production consists of various types of plants and livestock. Increasing diversification of agricultural products has consistently a positive relationship with food diversity. According to Sibhatu et al. (2015), the diversification of agricultural product has a positive effect on the diversification of food consumption.

The KRPL group has an ideal value in grains and nuts food groups, which is at a maximum value according to the requirement standard value of 25 for grains and 10 for nuts. In the food groups of animal foods and vegetables and fruits, the KRPL group does not meet an ideal value, but has a higher value than the non-KRPL group.

\section{Analysis of Energy Consumption}

Based on the analysis results, the average energy consumption of the KRPL and the Non-KRPL groups can be seen in the following table.

Table 10. Average Energy Consumption of KRPL group and Non-KRPL group

\begin{tabular}{llccc}
\hline No & Village & Standard & \multicolumn{2}{c}{ Energi Consumption } \\
\cline { 3 - 4 } & & & KRPL Group & Non-KRPL Group \\
\hline 1. & Gumingsir & 2,150 & $1,731.9$ & $1,560.2$ \\
2. & Masaran & 2,150 & $1,706.7$ & $1,602.4$ \\
3. & Darmayasa & 2,150 & $1,790.7$ & $1,490.7$ \\
4. & Sikumpul & 2,150 & $1,757.5$ & $1,538.9$ \\
5. & Gembongan & 2,150 & $1,721.1$ & $1,606.3$ \\
\hline
\end{tabular}

Source: Primary Data Processed

The average energy consumption based on SPSS analysis is as follows:

Table 11. Group Statistic of Analysis Result of Energy Consumption Using SPSS

\begin{tabular}{llrlrr}
\hline & Group & N & Mean & Std. Deviation & Std. Error Mean \\
\hline Energy & KRPL & 105 & 1741.5867 & 195.57716 & 19.08638 \\
& Non-KRPL & 85 & 1561.3812 & 186.69862 & 20.25031 \\
\hline
\end{tabular}

Source: Primary Data Processed

Table 12. Independent Samples Z Test of Analysis Result of Energy Consumption Using SPSS

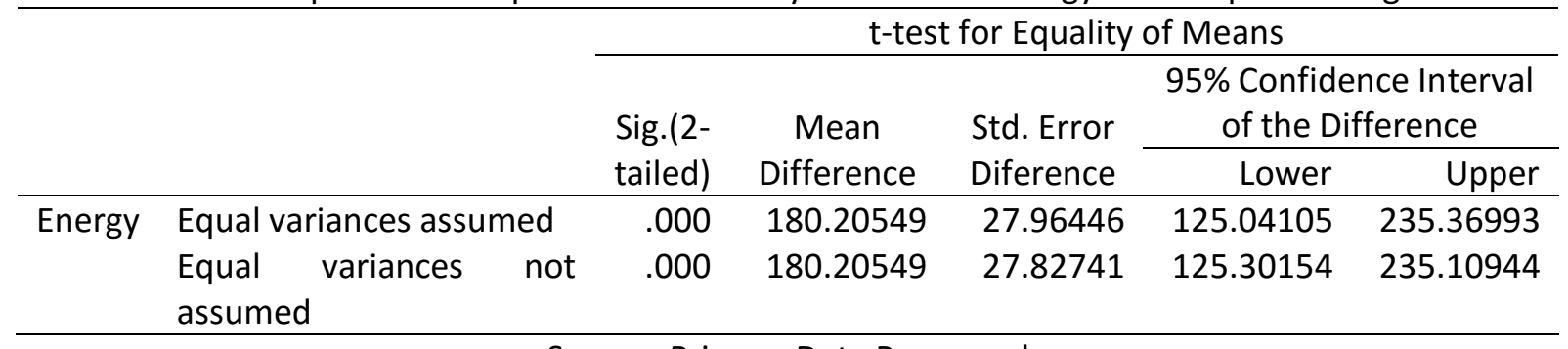

Source: Primary Data Processed 
Based on the table of output of independent samples $z$ test in the Equal Variances Assumed section, it is obtained Sig. (2-tailed) value of $0.000<0.005$, then as the basis for decision making in the independent samples $\mathrm{t}$ test, it can be concluded that $\mathrm{H}_{0}$ is rejected and $\mathrm{H}_{\mathrm{a}}$ is accepted. Thus, it can be concluded that there is a significant difference in energy consumption between the KRPL group and the non-KPRL group.

Based on the results of this study, the energy consumption is $1,741.5867 \mathrm{kcal} / \mathrm{cap} /$ day for the KRPL group and 1,561.3812 kcal/cap/day. Based on the regulation of Minister of Health No. 75 of 2013, the average energy adequacy for Indonesia's population is $2,150 \mathrm{kcal} / \mathrm{cap} / \mathrm{day}$ at the consumption level. This indicates that the KPRL program has an effect on the level of energy adequacy. The energy consumption of the KRPL group is higher than the non-KRPL group, although it does not meet the adequacy rate of energy. During the assistance of KRPL program, the members received assistance and knowledge about balanced nutrition consumption patterns in accordance with the minimum nutritional standard for their activities.

\section{Analysis of Protein Consumption}

Based on the analysis results, the average protein consumption of the KRPL and the non-KRPL groups can be seen in the following table:

Table13 .Average Protein Consumption of KRPL and Non-KRPL Groups

\begin{tabular}{ccccc}
\hline \multirow{2}{*}{ No } & \multirow{2}{*}{ Village } & \multirow{2}{*}{ Standard } & \multicolumn{2}{c}{ Protein Consumption } \\
\cline { 4 - 5 } & & 50 & 63.8 & KRPL Group \\
\hline 1. & Gumingsir & 50 & 56.4 & 46.5 \\
2. & Masaran & 50 & 65.5 & 40.5 \\
3. & Darmayasa & 50 & 62.2 & 52.0 \\
4. & Sikumpul & 50 & 63.3 & 49.6 \\
5. & Gembongan & & 50.9 \\
\hline
\end{tabular}

Source: Primary Data Processed

Average protein consumption based on SPSS analysis is as follows:

Table 14. Group Statistic of Analysis Result of Protein Consumption

\begin{tabular}{rlrrrr}
\hline & Group & N & Mean & \multicolumn{1}{c}{ Std. Deviation } & \multicolumn{1}{c}{ Std. Error Mean } \\
\hline \multirow{2}{*}{ Protein } & KRPL & 105 & 62.2571 & 12.50495 & 1.22036 \\
& Non-KRPL & 85 & 49.2024 & 12.10345 & 1.31280 \\
\hline
\end{tabular}

Source: Primary Data Processed

Table 15. Result of Independent Samples z Test of Protein Consumption



Source: Primary Data Processed

Based on the table of output of indepent samples $z$ test in the Equal Variances Assumed section, it is obtained Sig. (2-tailed) value of $0.000<0.005$, then as the basis for decision making in the independent samples $\mathrm{t}$ test, it can be concluded that $\mathrm{H}_{\mathrm{o}}$ is rejected and $\mathrm{H}_{\mathrm{a}}$ is accepted. Thus, it can be concluded that there is a significant difference in protein consumption between the KRPL group and the non-KRPL group.

Based on the results of this study, the protein consumption is 62.2571 grams/cap/day in the KRPL group and 49.2024 grams/cap/day in the non-KRPL group. Based on the regulation of Minister 
of Health No. 75 of 2013, the average protein adequacy for the Indonesian population is 57 grams/cap/day at the consumption level. This indicates that KRPL program has an effect on the adequacy rate of protein. Protein consumption in the KRPL group has met the adequacy rate of protein, while the non-KRPL group has not met the adequacy rate of protein. KRPL group received assistance and guidance in balanced nutrition consumption patterns to support the improvement of family nutrition.

\section{Food Expenditure}

Based on the analysis results, the average household foodstuff expenditure of KRPL and non-KRPL groups can be seen in the following table:

Table 16. Average Household Foodstuff Expenditure of KRPL and Non-KRPL Groups

\begin{tabular}{llcc}
\hline \multirow{2}{*}{ No } & & \multirow{2}{*}{ Village } & \multicolumn{2}{c}{ Foodstuff Expenditure } \\
\cline { 3 - 4 } & & KRPL Group (Rp) & Non-KRPL Group Rp) \\
\hline 1. & Gumingsir & $29,455.00$ & $41,063.00$ \\
2. & Masaran & $21,379.00$ & $39,276.00$ \\
3. & Darmayasa & $35,795.00$ & $41,762.00$ \\
4. & Sikumpul & $31,486.00$ & $37,744.00$ \\
5. & Gembongan & $41,524.00$ & $38,975.00$ \\
\hline
\end{tabular}

Source: Primary Data Processed

$Z$ test for foodstuff expenditure based on SPSS analysis is as follows:

Table 17. Group Statistic of Analysis Result of Household Foodstuff Expenditure

\begin{tabular}{llrcrr}
\hline & Group & $\mathrm{N}$ & Mean & Std. Deviation & Std. Error Mean \\
\hline Expenditure & KRPL & 105 & 31720.2381 & 11279.45295 & 1100.76190 \\
& Non KRPL & 85 & 39434.1176 & 10274.86810 & 1114.46592 \\
\hline
\end{tabular}

Source : Primary Data Processed

Table 18. Result of Independent Samples z Test of Household Foodstuff Expenditure

\begin{tabular}{|c|c|c|c|c|c|c|}
\hline & & \multicolumn{5}{|c|}{ t-test for Equality of Means } \\
\hline & & \multirow{2}{*}{$\begin{array}{l}\text { Sig.(2- } \\
\text { tailed) }\end{array}$} & \multirow{2}{*}{$\begin{array}{c}\text { Mean } \\
\text { Difference }\end{array}$} & \multirow{2}{*}{$\begin{array}{l}\text { Std. Error } \\
\text { Diference }\end{array}$} & \multicolumn{2}{|c|}{$\begin{array}{c}95 \% \text { Confidence Interval of } \\
\text { the Difference }\end{array}$} \\
\hline & & & & & Lower & Upper \\
\hline \multirow[t]{2}{*}{ Expenditure } & $\begin{array}{l}\text { Equal variances } \\
\text { assumed }\end{array}$ & .000 & 7713.87955 & 1581.92654 & -10834.48703 & -4593.27208 \\
\hline & $\begin{array}{l}\text { Equal variances } \\
\text { not assumed }\end{array}$ & .000 & 7713.87955 & 1566.43258 & -10804.20824 & -4623.55087 \\
\hline
\end{tabular}

Source: Primary Data Processed

Based on the table of output of independet samples $z$ test in the Equal Variances Assumed section, it is obtained Sig. (2-tailed) value of $0.000<0.005$, then as the basis for decision making in the independent samples $\mathrm{t}$ test, it can be concluded that $\mathrm{H}_{0}$ is rejected and $\mathrm{H}_{\mathrm{a}}$ is accepted. Thus, it can be concluded that there is a significant difference in the foodstuff expenditure between the KRPL group and the non-KRPL group.

The results indicate that KRPL program has an effect on household foodstuff expenditure. The yard utilization can increase food availability, so that there will be savings on foodstuff expenditure. Based on the analysis result of foodstuff expenditure, the KRPL group has lower foodstuff expenditure than the non-KRPL group. The average foodstuff expenditure of KRPL group is Rp31,720.24, while the average food expenditure of non-KRPL group is Rp39,343.12. 


\section{CONCLUSION}

From the analysis conducted by the researcher, it indicated that there were significant differences in DDP scores, energy consumption, protein consumption and foodstuff expenditure between KRPL group and non-KRPL group. DDP score, energy consumption, protein consumption of KRPL group was higher than those in non-KRPL group. This was because the optimization of yard utilization through the KRPL program increased the availability and access of foods, especially vegetables, fruits, and animal foods at the household level. These conditions increased household food consumption and eventually increased DDP scores, energy consumption, and protein consumption. Whereas the household foodstuff expenditure in KRPL group was lower than in non-KRPL group. This was due to the savings of the KRPL group on foodstuff expenditure. Some food needs of KRPL group were obtained from selfproduction so that they did not need to spend money to shop for foodstuffs. On the other hand, the non-KRPL group had to shop for foodstuffs to meet their food needs. The conclution is that in an effort to increase DDP score, energy consumption, protein consumption and to save household foodstuff expenditure.

\section{REFERENCES}

Badan Ketahanan Pangan, 2010. Peraturan Menteri Pertanian Tahun 2010 tentang Standart Pelayanan Minimal Bidang Ketahanan Pangan Provinsi dan Kabupaten/Kota. Badan Ketahanan Pangan Kementerian RI, Jakarta 2018 Petunjuk Teknis Optimalisasi Pemanfaatan Pekarangan Melalui Kawasan Rumah Pangan Lestari (KRPL) 2018. Badan Ketahanan Pangan Kementerian RI, Jakarta 2018. Laporan Kinerja Badan Ketahanan Pangan 2017. Badan Ketahanan Pangan Kementerian RI, Jakarta

Dinas Ketahanan Pangan Provinsi Jawa Tengah. 2017. Panduan Menghitung Pola Pangan Harapan. Dinas Ketahanan Pangan Prov. Jateng, Ungaran

Dinas Ketahanan Pangan Kab. Banjarnegara. 2018. Laporan Kinerja Instansi Pemerintah Tahun 2018. Dinas Ketahanan Pangan Kab. Banjarnegara, Banjarnegara

Fatmah. 2014. Media Komunikasi, Informasi dan Edukasi Gizi. Erlangga : Jakarta

Frison, E.A., Jeremy Cherfas dan Toby Hodgkin. 2011. Agricultural Biodiversity Is Essential for a Sustainable Improvement in Food and Nutrition Security. 3(1): 238-253. https://doi.org/10.3390/su3010238

Hermanto. 2015. Ketahanan Pangan Indonesia Di Kawasan Asean. Pusat Sosial Ekonomi dan Kebijakan Pertanian. Doi: http://dx.doi.org/10.21082/fae.v33n1.2015.19-31

Hermina \& Prihatini S. 2014. Gambaran Konsumsi Sayur dan Buah Penduduk Indonesia dalam Konteks Gizi Seimbang: Analisis Lanjut Survei Konsumsi Makanan Individu (SKMI) 2014. Buletin Penelitian Kesehatan, 44 (3): 205-218. Doi:10.22435/bpk.v44i3.5505.205-218

Galhena. D. H, Russell Freed \& Karim M Maredia. 2013. Home gardens : a promising approach to enhance household food security and wellbeing. Agriculture \& Food Security 2013, Retrieved from https://agricultureandfoodsecurity.biomedcentral.com/articles/10.1186/2048-7010-2-8

Istiqomah and Fitrijati, K.R., 2015. Empowerment Of Women Farmer Groups To Promote Rural Development In Central Java, Indonesia. Internaional Journal of Applied Bussiness and Economic Research, Vol. 13, No. 7 (2015): 5421-5433.

Jones.A.D., Aditya Shrinivas \& Rachel Bezner-Kerr. 2014. Farm production diversity is associated with greater household dietary diversity in Malawi: Findings from nationally representative data. Food Policy, 46: $1-12$.

Menteri Kesehatan RI. 2013. Peraturan Menteri Kesehatan RI Nomor 75 Tahun 2013 tentang Angka Kecukupan Gizi yang Dianjurkan bagi Bangsa Indonesia. Kementerian Kesehatan RI : Jakarta

Menteri Pertanian RI. 2010. Peraturan Menteri Pertanian Nomor : 65/Permentan/OT.140/12/2010 tentang Strandar Pelayanan Minimal Bidang Ketahanan Pangan Provinsi dan Kabupaten/Kota. Kementerian Pertanian RI: Jakarta

Presiden RI, 2012. Undang-undang Nomor 18 tentang Pangan. Pemerintah Pusat, Jakarta Putrawan, I Made. 2017. Pengujian Hipotesis dalam Penelitian-penelitian. Bandung: Alfabeta. 
Home Garden, Desirable .... (Wuriyaningrum, et al.)

Sibhatu.K.T., Vijesh V. Krishna \& Matin Qaim. 2015. Production Diversity And Dietary Diversity In Small Holder Farm Household, 112 (34), 10657-10662. DOI: 10.1073/pnas.1510982112

Sugiyono. 2017. Metode Penelitian Kebijakan. Bandung : Alfabeta. 